\title{
The Bambuta Phosphate Deposit, Liberia- A Reconnaissance Report
}

G E O L O G I C A L S U R VEY B U L L E T I N 14880

Prepared in cooperation with the Liberian Geological Survey under the sponsorship of the Agency for International Development, U.S. Department of State
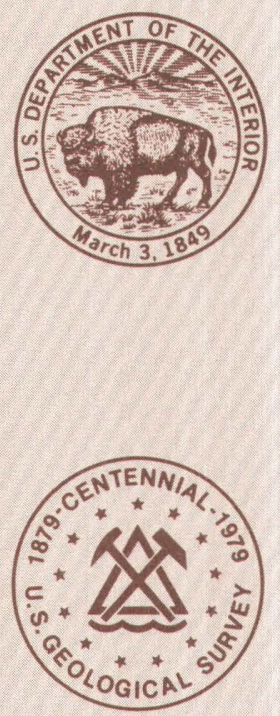



\section{The Bambuta Phosphate Deposit, Liberia- A Reconnaissance Report}

By SAM ROSENBLUM and S. P. SRIVASTAVA

GE O L O G I C A L S U R V E Y B U L L E T I N 1480

Prepared in cooperation with the Liberian Geological Survey under the sponsorship of the Agency for International Development, U.S. Department of State

An unusual deposit of iron and aluminum

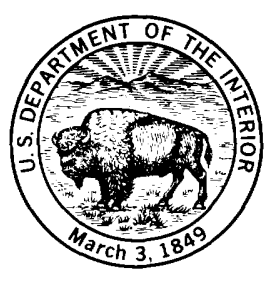
phosphates of at least 1.5 million tons containing 28 percent $\mathrm{PO}_{5}$ 


\section{UNITED STATES DEPARTMENT OF THE INTERIOR}

CECIL D. ANDRUS, Secretary

\section{GEOLOGICAL SURVEY}

H. William Menard, Director

Library of Congress Cataloging in Publication Data

Rosenblum, Sam

The Bambuta Phosphate Deposit, Liberia-A Reconnaissance Report

(Geological Survey Bulletin 1480)

Bibliography: P. 25

1. Phosphates-Liberia. I. Srivastava, S. P., joint author. II. Liberia. Geological Survey.

III. Title. IV. Series: United States Geological Survey Bulletin 1480.

QE75.B9 no. $1480 \quad$ [TN914.L7] 557.3'08s [549'.72] 79-14259

For sale by the Superintendent of Documents, U.S. Government Printing Office

Washington, D.C. 20402

Stock No. 024-001-03246-5 


\section{CONTENTS}

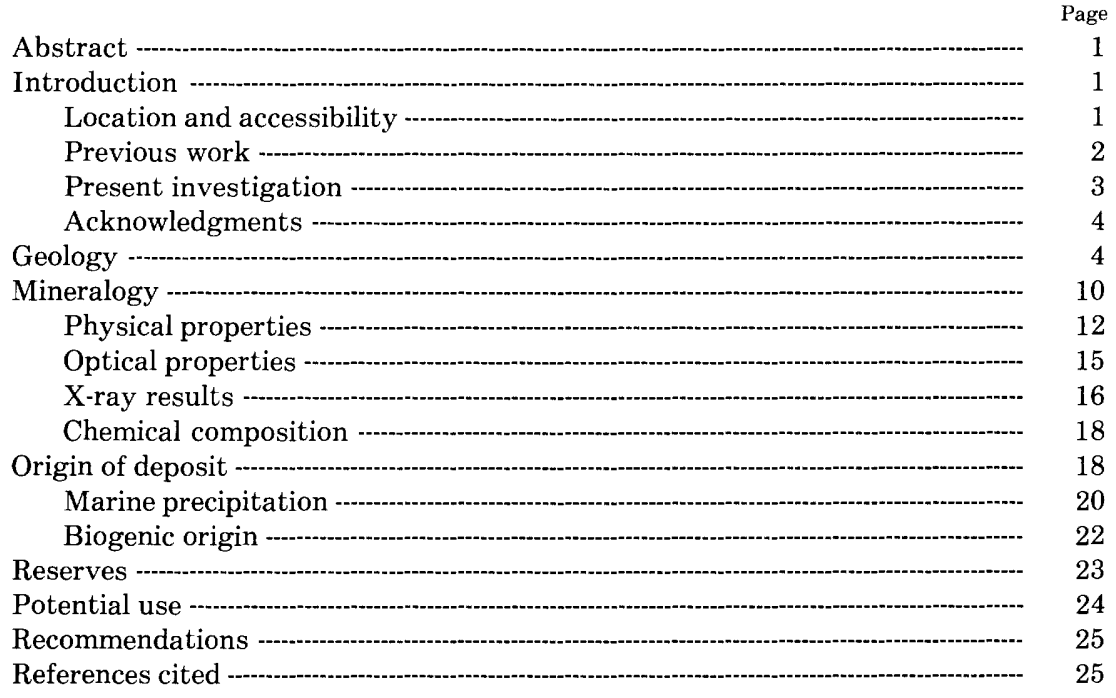

\section{ILLUSTRATIONS}

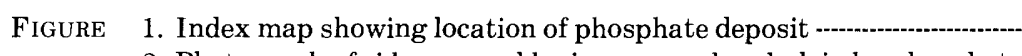

2. Photograph of ridge capped by iron ore and underlain by phosphate rock

3. Geologic map and cross sections of the Bambuta phosphate deposit -

4-8. Photographs showing:

4. Bold magnetite-martite outcrop showing distinct foliation

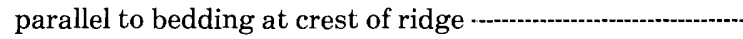

5. Sheared granitic gneiss west of the Bambuta phosphate area -----------------------------------

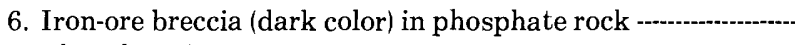

7. Phosphate in iron ore --o---o---o-

8. Types of phosphate rock from drill hole BB-38 and several outcrops

9. Photomicrographs showing martite replaced by phosphate minerals

10. Photomicrograph of a grain mount of phosphate minerals from drill-core BB-38 at $25.3 \mathrm{~m}$ depth 


\section{TABLES}

Page

TABLE 1. X-ray powder diffraction data on strengite from the phosphate deposit 17

2. Phosphate minerals identified in drill cores 18

3. Chemical composition of phosphate samples 19 


\title{
THE BAMBUTA PHOSPHATE DEPOSIT, LIBERIA-A RECONNAISSANCE REPORT
}

\author{
By Sam Rosenblum and S. P. SRivastava ${ }^{1}$
}

\section{ABSTRACT}

A layer of iron and aluminum phosphates as much as 38 meters (m) near Bambuta, Liberia, lies on granitic gneiss and is overlain by metasedimentary iron-formation that is an extension of the iron-formation at Bomi Hills. The deposit is $70 \mathrm{~km}$ north of Monrovia and $25 \mathrm{~km}$ east of the Bomi Hills iron mine.

The phosophate minerals, mainly members of the orthorhombic variscite-strengite series, are generally iron bearing in the upper part of the deposit and tend to be more aluminous in the lower part. The Bambuta phosphate deposit may be metasedimentary in origin or it may have been formed by replacement of iron-formation and granitic gneiss by phosphatic solutions moving laterally from an organic source.

Diamond drilling has shown minimum reserves of about 1 million metric tons of phosphate rock containing about 32 percent $\mathrm{P}_{2} \mathrm{O}_{5}$, or 1.5 million tons containing 28 percent $\mathrm{P}_{2} \mathrm{O}_{5}$. Further exploration may increase these estimates of the reserves.

\section{INTRODUCTION}

\section{LOCATION AND ACCESSIBILITY}

The phosphate deposit near Bambuta is in Liberia Mining Co. (LMC) concession Lot 3C, $70 \mathrm{~km}$ north-northeast of Monrovia and 25 $\mathrm{km}$ east of Bomi Hills iron mine, the principal mine operated by LMC (fig. 1). The nearest town is Bambuta, $1.7 \mathrm{~km}$ northeast of the phosphate deposit. That name was used to designate the deposit (Axelrod and others, 1952), but no official name has yet been assigned to the small area in which the deposit is located. The Bambuta phosphate deposit is easily reached by a good laterite-surfaced road from the Bomi Hills mine (fig. 2) or by an inferior road connecting Monrovia and Bopolu that passes about $1 \mathrm{~km}$ east of the phosphate deposit (fig. 1).

The phosphate deposit is associated with iron-formation and iron ore that support a prominent ridge crossed by the road to Bomi Hills

${ }^{1}$ With the Liberia Geological Survey, deceased July 1979. 
(figs. 1 and 2). The iron ore on the northwest flank of this ridge had been mined out before this investigation (1969-70), and mining operations had been started on the south side.

\section{PREVIOUS WORK}

Phosphate minerals at Bomi Hills and Bambuta were briefly described by Axelrod, Carron, Milton, and Thayer (1952) who iden-

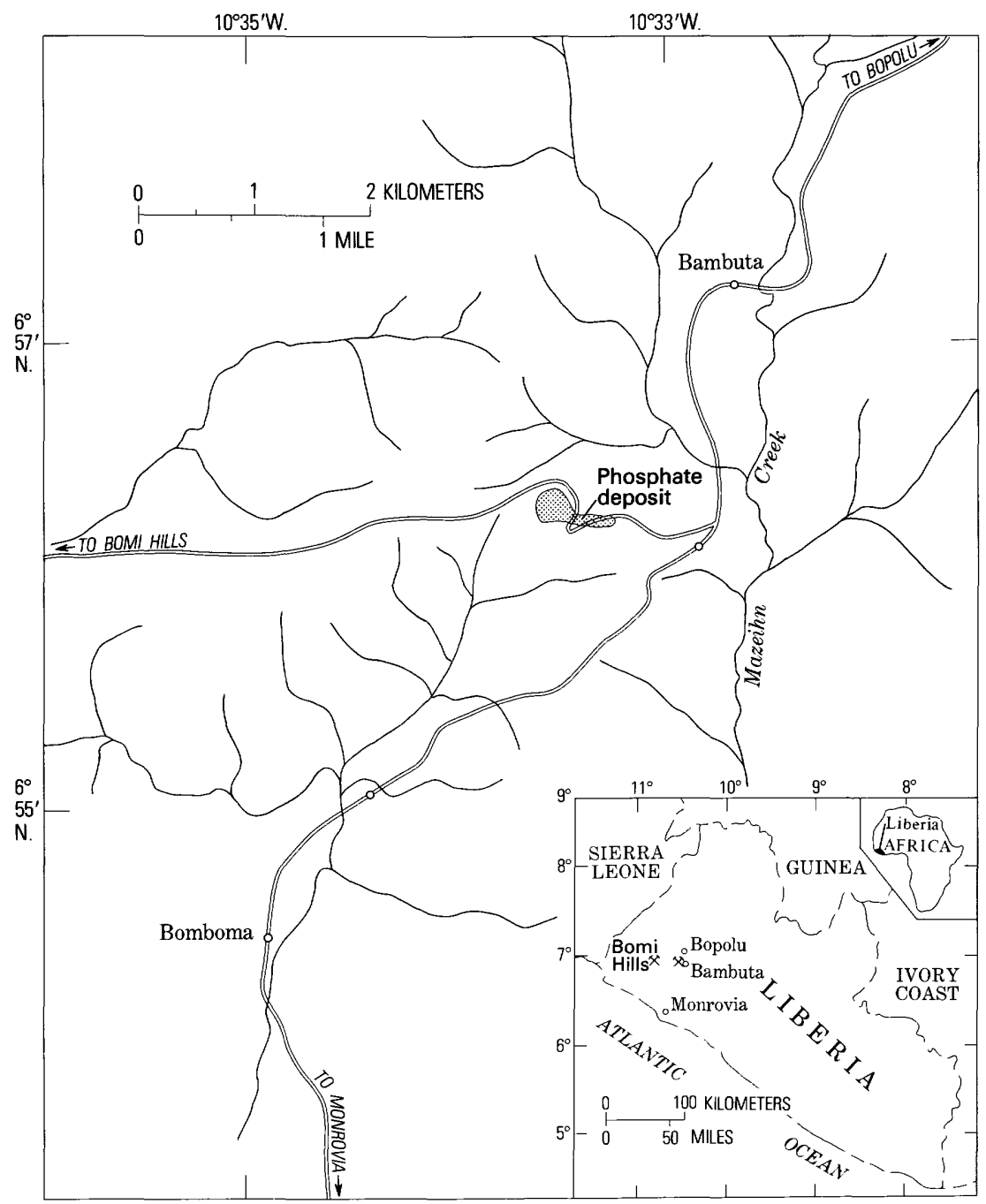

FIGURE 1.-Index map showing location of phosphate deposit near Bambuta, Liberia. Unlabeled circles are groups of houses. 


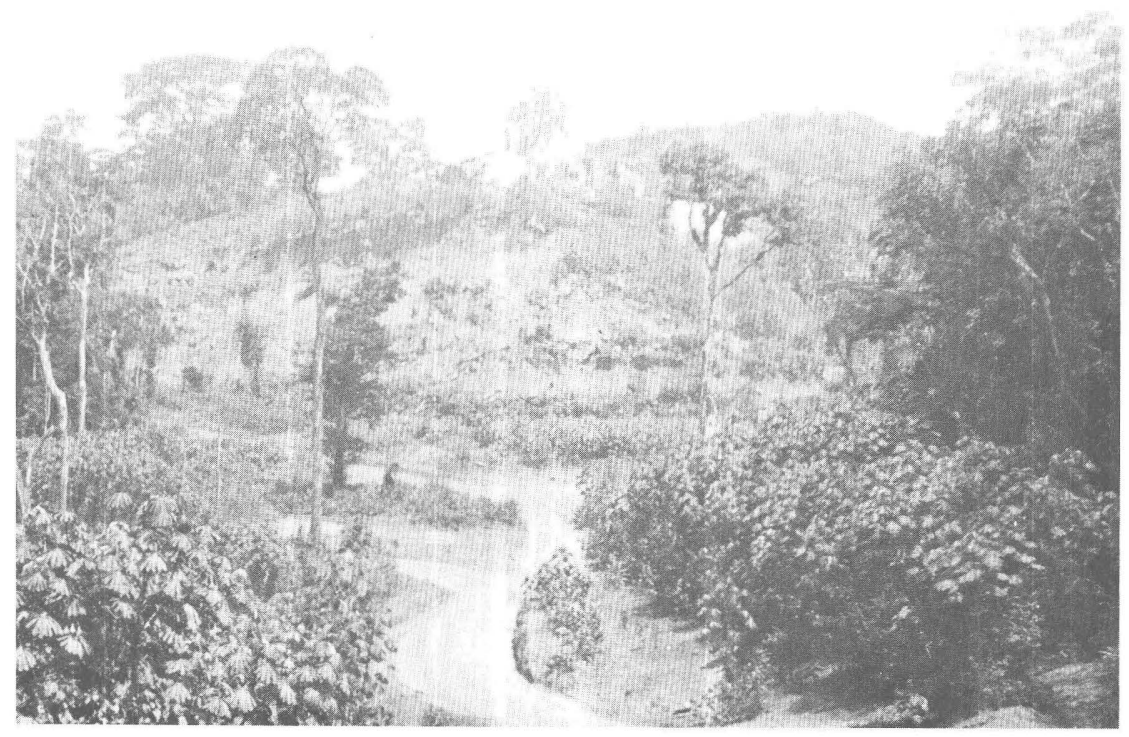

FIGURE 2.-Ridge capped by iron ore and underlain by phosphate rock. View east along road from Bomi Hills.

tified phosphosiderite and strengite at both localities; in addition, leucophosphite and other phosphate minerals were found at Bomi Hills. Moreover, this is one of the earliest reported occurrences of leucophosphite.

The presence of high-grade phosphate rock in the Bambuta area became evident in 1969 after two outcrop samples analyzed by the Mineralogy Laboratory of the Liberian Geological Survey (LGS) were found to consist of aluminum phosphates containing 32 to 36 percent phosphate, reported as $\mathrm{P}_{2} \mathrm{O}_{5}$ (Srivastava, 1971). About the same time, a resource study of the iron-formation and other rocks in the area was made by W. E. Stewart and D. A. Dinkins, geologists of LGS, and W. A. Freeman, mining engineer of the Mining Service (Stewart, and others, 1969).

\section{PRESENT INVESTIGATION}

The possibility that the phosphate rock near Bambuta might be a potential mineral resource led to a preliminary examination of outcrop material by the writers in 1969. This work was done as part of a geologic- and minerals-appraisal program undertaken jointly by the LGS and the U.S. Geological Survey (USGS) under the sponsorship of the government of Liberia and the Agency for International Development (USAID), U.S. Department of State. The examination 
was followed by geologic mapping and core drilling conducted by LMC, which operated the property. The drilling results disclosed a considerable tonnage of high-grade phosphate rock composed of minerals of the variscite-strengite series. These minerals are iron and aluminum phosphates not ordinarily used in commerce. However, they might serve as fertilizer if used locally under appropriate conditions. The present investigation was made to identify the minerals and chemical characteristics of the Bambuta phosphate deposit and to evaluate it as a Liberian mineral resource. The estimates of reserves are based on the results of exploration by LMC, including 25 drill holes and reconnaissance mapping (Peter Van Rooijen, written communication, 1971).

\section{ACKNOWLEDGMENTS}

We wish to acknowledge the generous assistance of the following individuals and institutions who cooperated with us in this investigation: Charles Milton, George Washington University, Washington, D.C., for X-ray confirmation of the aluminum phosphates, variscite and augelite, in the first two outcrop samples examined; the U.S. Tennessee Valley Authority (TVA), Division of Chemical Development, and Rod MacDonald, Engineer, USAID, Liberia, for chemical analysis of a phosphate sample; R. E. Guth, General Manager, and Peter Van Rooijen, Geologist, LMC, for permission to examine the phosphate area and for making available unpublished reports, geologic maps, cross sections, and phosphate-rock samples from the drill cores; Ronald Ames, Soil Chemist, Liberian Agricultural Company, for testing samples of pulverized phosphate to determine the efficiency of the material as a fertilizer; David Pegum, Geophysicist, United Nations Mineral Survey, for testing radioactivity of samples; J. B. Cathcart, USGS, and E. L. Phillips, LGS, for X-ray identification of the phosphate minerals in several core samples.

\section{GEOLOGY}

The Bambuta phosphate deposit is exposed just below the crest of a ridge that rises 30 to $120 \mathrm{~m}$ above the general terrain (figs. 2 and 3). The ridge is capped by iron-formation that normally lies conformably on polymetamorphic, coarsely layered to finely laminated granitic (biotitic quartzo-feldspathic) gneiss (figs. 4 and 5). The foliation of the gneiss strikes about $\mathrm{N}$. $70^{\circ} \mathrm{E}$. and dips from $60^{\circ} \mathrm{NW}$. to vertical. Iron-formation, consisting chiefly of itabirite, iron-silicate formation, lenses of quartzite at least $70 \mathrm{~m}$ thick, and masses of amphibolite as much as $50 \mathrm{~m}$ thick, is commonly folded into the gneiss in this part of Liberia (White and Leo, 1969, p. 7-8). The iron-formation capping the 
ridge contains local pods of ore-grade magnetite and/or martite (R. D. Jones and Bernard LeFevre, Jr., written communication, 1964).

Aeromagnetic data indicate the iron-formation near Bambuta is an easterly extension of the iron ore at Bomi Hills (Behrendt and Wotorson, 1974). Northwest-trending diabase dikes of the Gibi dike system crop out a few kilometers to the south of the area, and a few diabase dikes are exposed near Bopolu (White and Leo, 1969).

The metasedimentary rocks of the ridge have sinuous horizontal fold axes subparallel to the ridge line. The overall structure appears to be similar to the infolded iron-rich metasedimentary synclinoria in older granitic gneiss described by Thienhaus and Stobernack (1967) in the Bong Range, by Berge (1968) in the Nimba Range, by White (1973) and White and Leo (1969) elsewhere in Liberia. However, the extent of infolded metasedimentary rocks near Bambuta is much smaller than that described at the aforementioned places. Rubidiumstrontium ages (Hedge and others, 1975) ' of rocks from the Bong Mine indicate that the iron-formation is at least 2,750 million years old.

LMC's 25 drill holes, which disclosed a layer of phosphate rock as much as $38 \mathrm{~m}$ thick between the Precambrian iron-formation and the granitic gneiss, are along six north-south lines in an area about $150 \mathrm{~m}$ north-south and $360 \mathrm{~m}$ east-west along the ridge. Core from hole BB-53 (fig. 3) showed small lenses of iron-formation within the layer of phosphate rock as well as below the layer. From the drill-hole data and the general geology, we inferred that the phosphatic layer lies on a mature topography of weathered granitic gneiss and is in turn overlain by the main beds of iron-formation.

Iron ore south of the crest of the ridge is fractured and brecciated, and tan phosphate rock fills the fractures and the interstices among the breccia fragments in a zone about $30 \mathrm{~m}$ vertically below the highest peak and downslope to the south (fig. 6). Locally, considerable replacement of magnetite by phosphate minerals has taken place along the margins of phosphate-filled fractures (fig. 7). Analyses of iron ore overlying the phosphate layer showed tenors of $\mathrm{P}_{2} \mathrm{O}_{5}$ as high as 2.1 percent.

Rock exposed in the mined area to the northwest of the peak of the ridge is mainly well-fractured blocks of iron ore between minor faults. The layering in these blocks dips in various directions and amounts, and in places blocks of iron ore a few meters across are underlain by soft clayey rubble. Phosphate rock was not recognized in the mined area except for two masses in loose rubble on the northeast side of the excavation. Other rocks seen in this area were thin layers of ironformation and magnetite-rich schist, but attitudes of these were not apparent. 


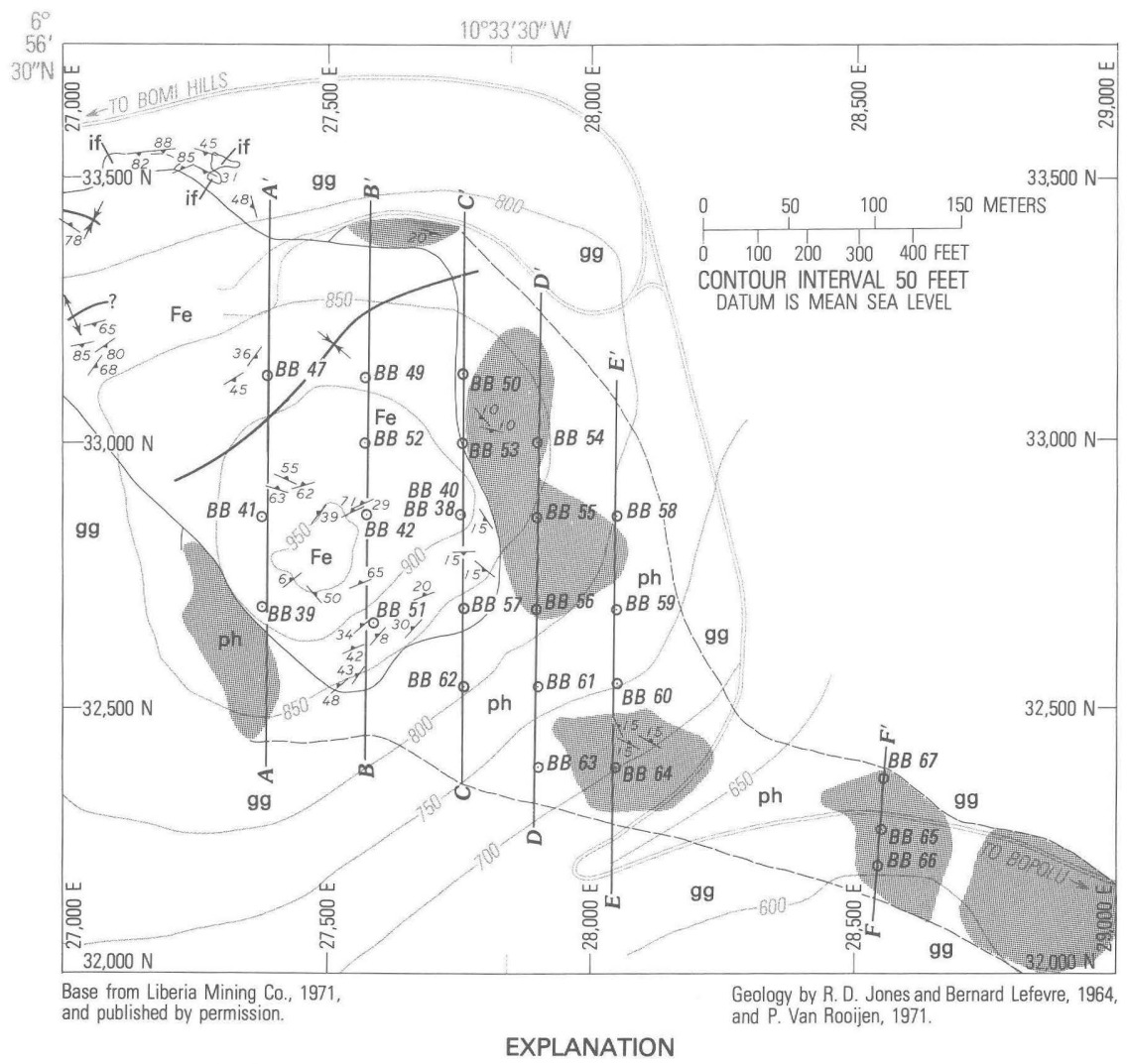

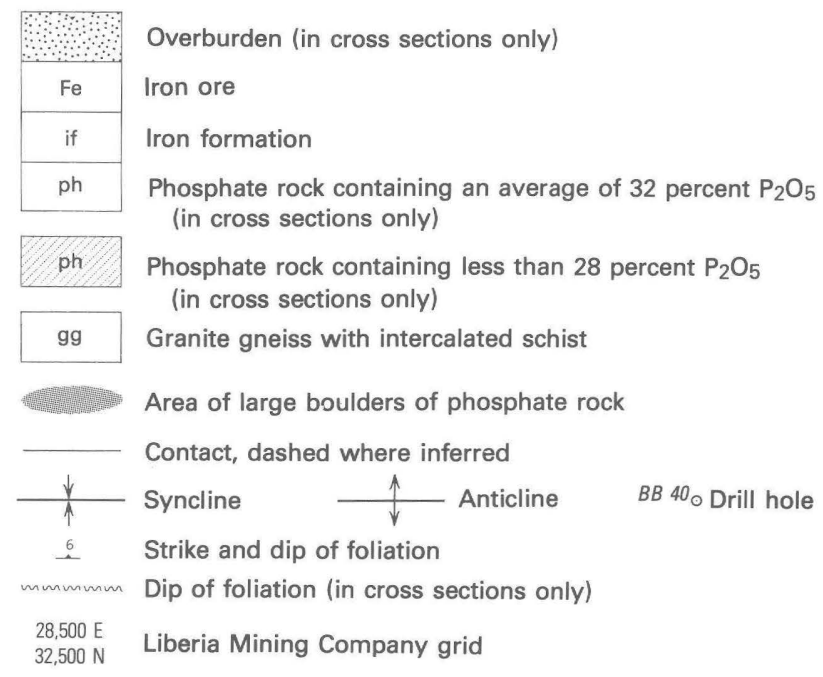

FIGURE 3.-Geologic map and cross sections of the Bambuta phosphate deposit. 


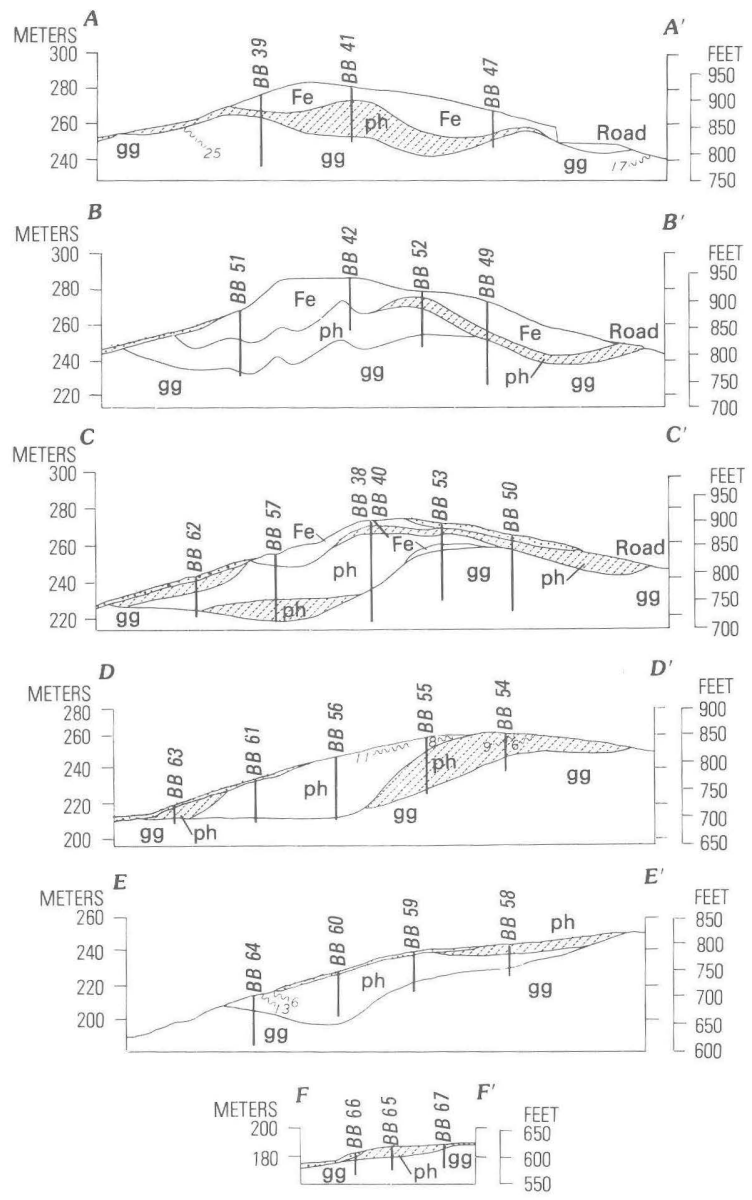

Figure 3.-Continued.

A moderately radioactive layer of phosphate rock at least $3 \mathrm{~m}$ thick and $60 \mathrm{~m}$ long dips about $20^{\circ} \mathrm{S}$. into the north side of the ridge where the radioactive layer is exposed in a road cut (north side of map area, fig. 3). The level of radioactivity of this layer, as measured by handheld scintillation counter, reached 250-300 counts per second (cps) compared to the background value of the granitic gneiss of $50 \mathrm{cps}$. No radioactive mineral was recognized in the field, but a test of a sample from this layer by gamma-ray spectrometer indicated that the radioactivity was due to uranium.

Two hundred and fifty meters southeast of the peak and about 90 $m$ lower in altitude the road crosses a zone of bouldery phosphate 


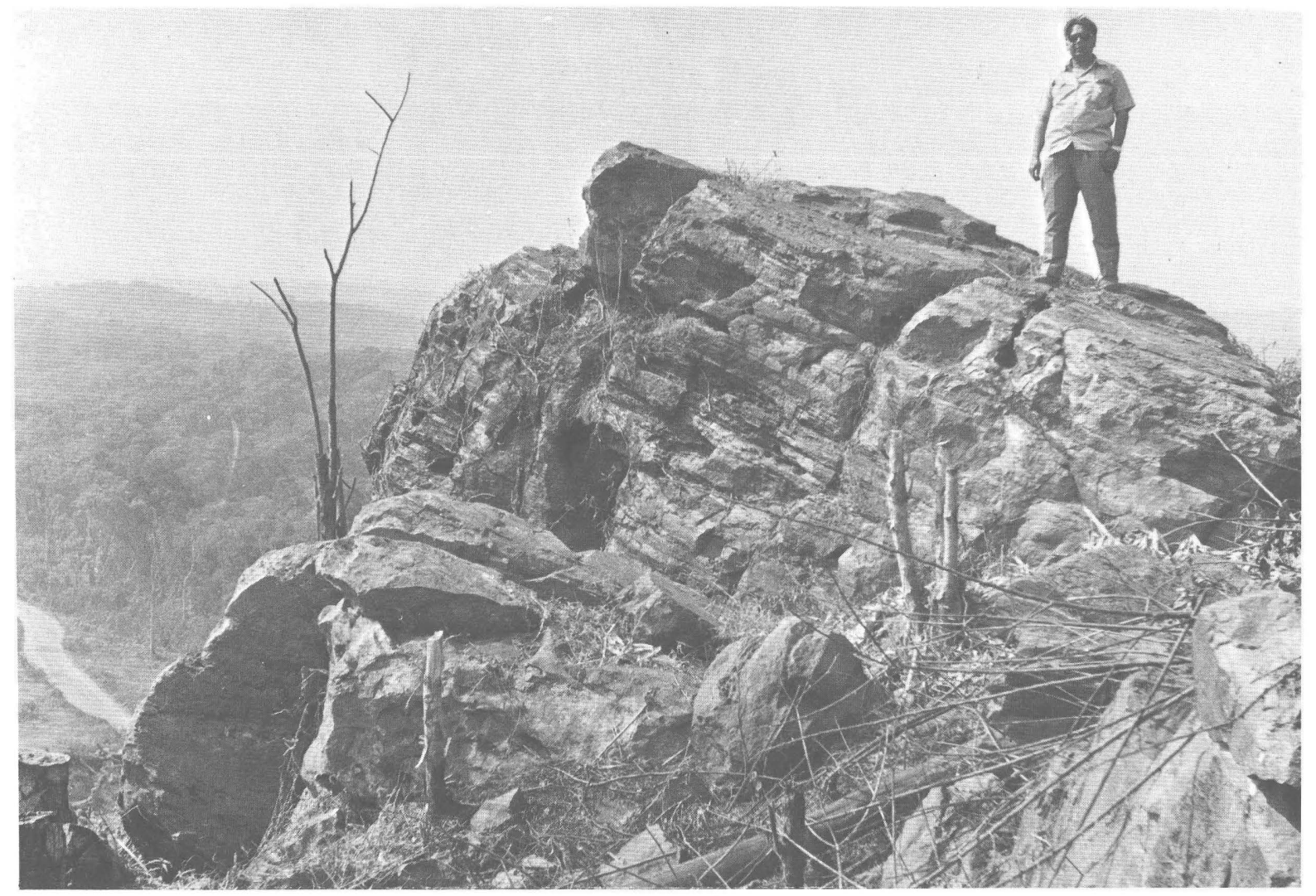




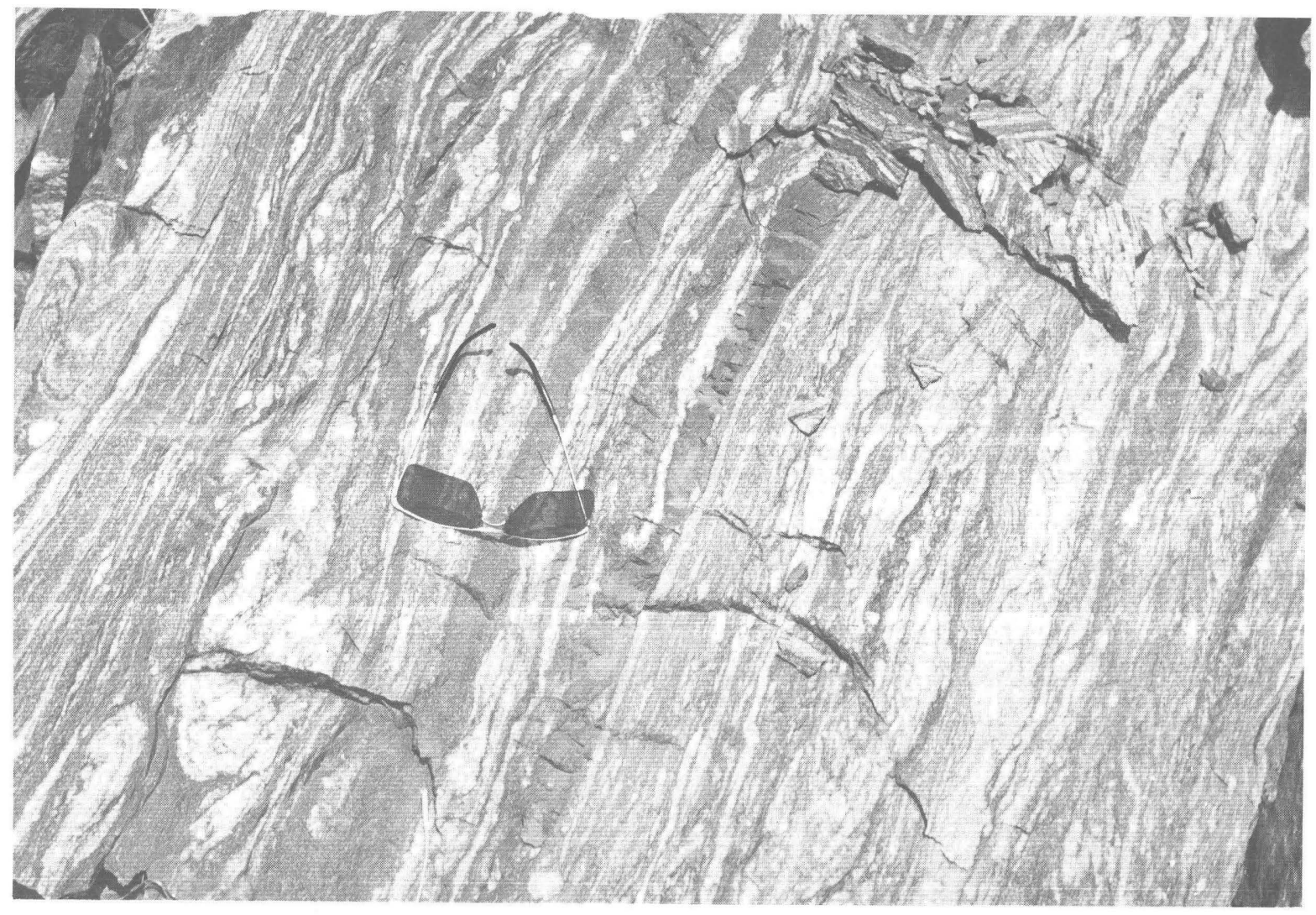

FIGURE 5.-Sheared granitic gneiss west of the Bambuta phosphate area, showing variation from fine laminae to coarse banding, a fold on left side, and boudinage. 


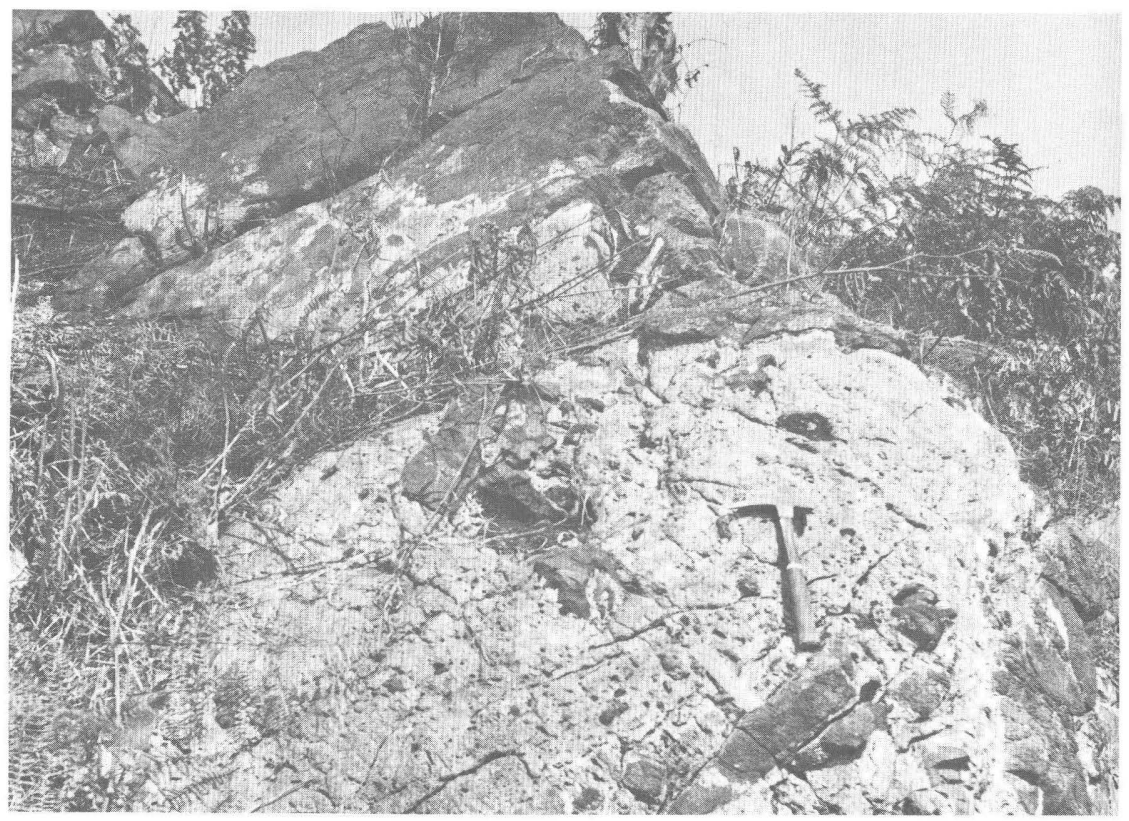

FIGURE 6.-Iron-ore breccia (dark color) in phosphate rock.

rock about $80 \mathrm{~m}$ wide. About $70-260 \mathrm{~m}$ east of this outcrop are two more exposures of phosphate rock about $70 \mathrm{~m}$ and $100 \mathrm{~m}$ across (fig. 3 ). The level of radioactivity at these outcrops was $120-160 \mathrm{cps}$.

In summary, the metasedimentary rocks that support the ridge near Bambuta are apparently the same as the sequence containing iron-formation and iron ore at Bomi Hills $25 \mathrm{~km}$ to the west and at Bong Mine $28 \mathrm{~km}$ to the east-southeast. However, only at Bambuta are these metasedimentary rocks known to include considerable phosphate rock underlying and interbedded with the iron-formation.

\section{MINERALOGY}

Phosphate minerals from this deposit were first identified by Axelrod, Carron, Milton, and Thayer (1952) as phosphosiderite and strengite, of which phosphosiderite was the more abundant. Their samples presumably were collected from outcrops and consisted of phosphate minerals that filled fractures in magnetite or that formed cement around iron-ore breccia.

In the present study, it was learned that the phosphate deposit is polymineralic and that the variation in the component phosphate 

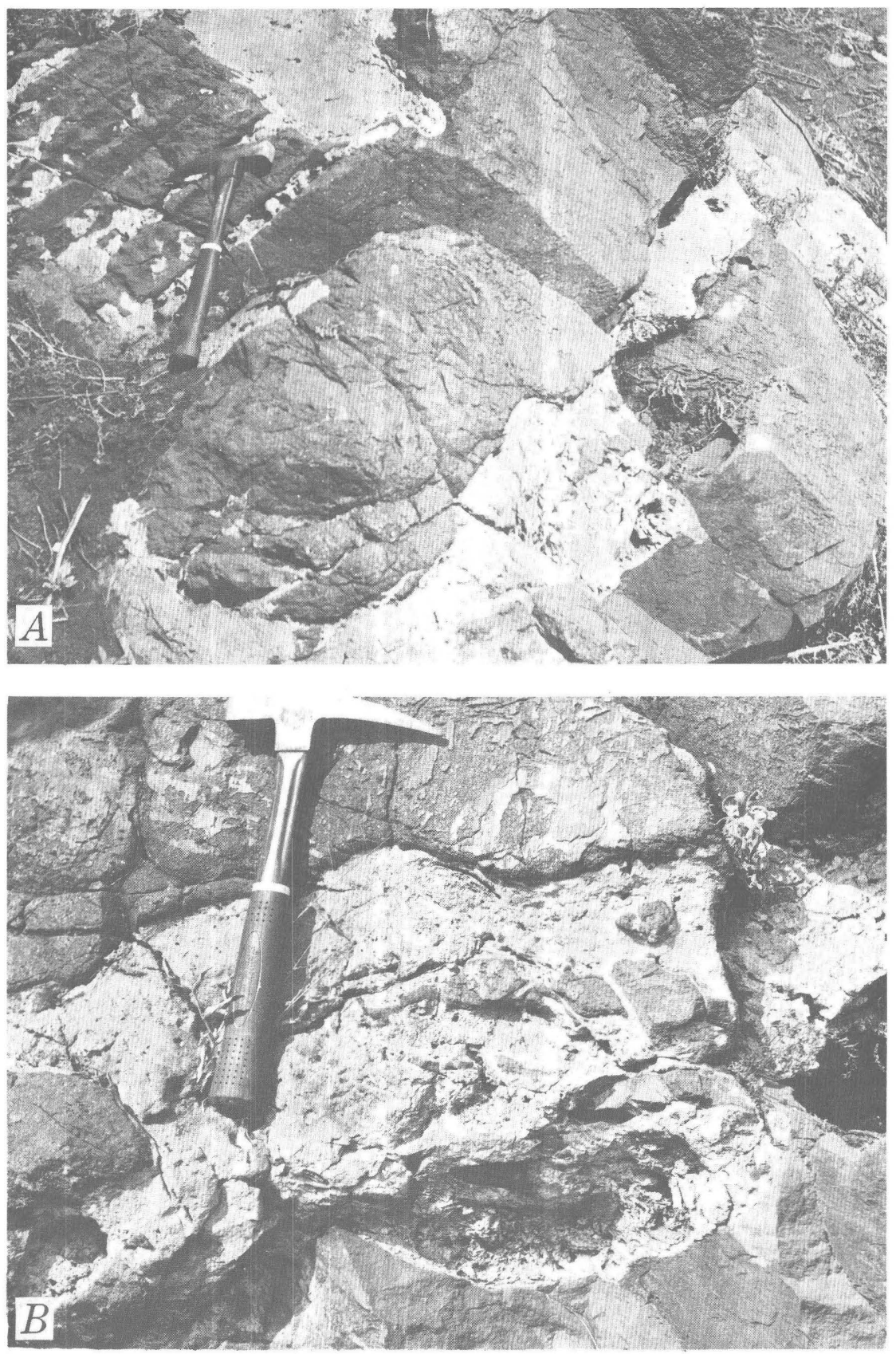

FIGURE 7.-Phosphate in iron ore; $A$, phosphate minerals fill fractures near lower contact of foliated iron ore; $B$, iron ore is partly replaced along fracture filling. 
minerals is nonsystematic. The main phosphate minerals identified by optical and X-ray methods are classified structurally and chemically as:

\begin{tabular}{ccc}
\hline Composition & Orthorhombic & Monoclinic \\
\hline $\mathrm{AlPO}_{4} \cdot 2 \mathrm{H}_{2} \mathrm{O} \ldots \ldots$ & Variscite & Clinovariscite (metavariscite) \\
$(\mathrm{Al}, \mathrm{Fe}) \mathrm{PO}_{4} \cdot 2 \mathrm{H}_{2} \mathrm{O} \ldots$ & Barrandite & Clinobarrandite \\
$\mathrm{FePO}_{4} \cdot 2 \mathrm{H}_{2} \mathrm{O} \ldots \ldots \ldots$ & Strengite & Clinostrengite (metastrengite, \\
& & phosphosiderite) \\
\hline
\end{tabular}

In addition, the following were identified in different samples and in small amounts: augelite, $\mathrm{Al}_{2} \mathrm{PO}_{4}(\mathrm{OH})_{3}$; barbosalite, $\mathrm{Fe}^{2+} \mathrm{Fe}^{3+} \mathrm{PO}_{4}$ $(\mathrm{OH})_{2}$; turquoise, $\mathrm{CuAl}_{6}\left(\mathrm{PO}_{4}\right)_{4}(\mathrm{OH})_{8} \cdot 5 \mathrm{H}_{2} \mathrm{O}$; and wavellite, $\mathrm{Al}_{3}\left(\mathrm{PO}_{4}\right)_{2}$ $(\mathrm{OH})_{3} .5 \mathrm{H}_{2} \mathrm{O}$.)

Surficial samples are locally rich in variscite or strengite, but subsurface samples are mainly aluminian strengite. Core samples include minerals in the orthorhombic variscite-strengite series and the monoclinic analog of strengite, clinostrengite. Subsurface samples generally do not show any systematic changes with depth, except that in drill-hole BB-38 (fig. 3) a gradual variation was found from iron-rich phosphate at $3 \mathrm{~m}$ to an aluminum-rich phosphate at $38 \mathrm{~m}$ depth. More detailed studies are required to better define the variations in mineralogical characters of this deposit.

\section{PHYSICAL PROPERTIES}

The physical properties of two surficial samples of phosphate rock described by Srivastava (1971) and 25 samples selected from cores from 10 drill holes in the Bambuta area are rather similar. The phosphate rock is generally well-consolidated earthy material. Most hand specimens are massive and chalky, but some are distinctly layered, including some outcrop samples (fig. 8, right side) that are porous and harder than the core samples. Some specimens of phosphate rock contain residual fragments of quartz or iron ore in a matrix of secondarily precipitated phosphate minerals. Under the microscope, core-samples BB-40/13.1 m and BB-38/39.6 m show partial to almost complete replacement of martite by phosphate minerals (fig. 9). Where replacement textures are observed, veins of younger phosphate minerals can be seen to cut across the replacing phosphate. In outcrops some white pisolitic nodules of phosphate as much as 5 millimeters $(\mathrm{mm})$ across were noted locally. Fossils were absent from all phosphatic material studied from this deposit. 


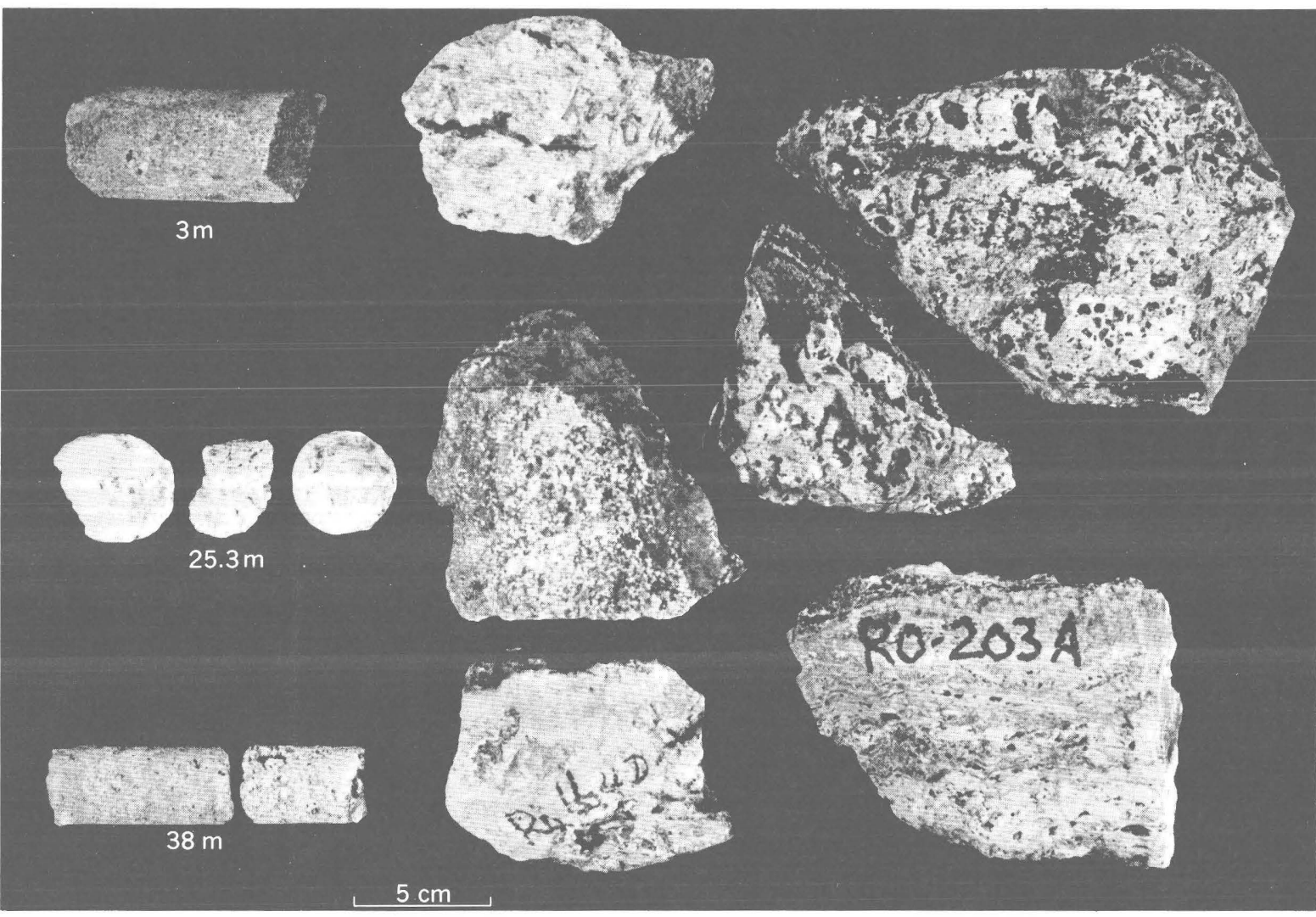

FIGURE 8.-Types of phosphate rock from drill hole BB-38 and several outcrops; iron ore is in breccia at upper right, and the other samples show porous and layered features. 


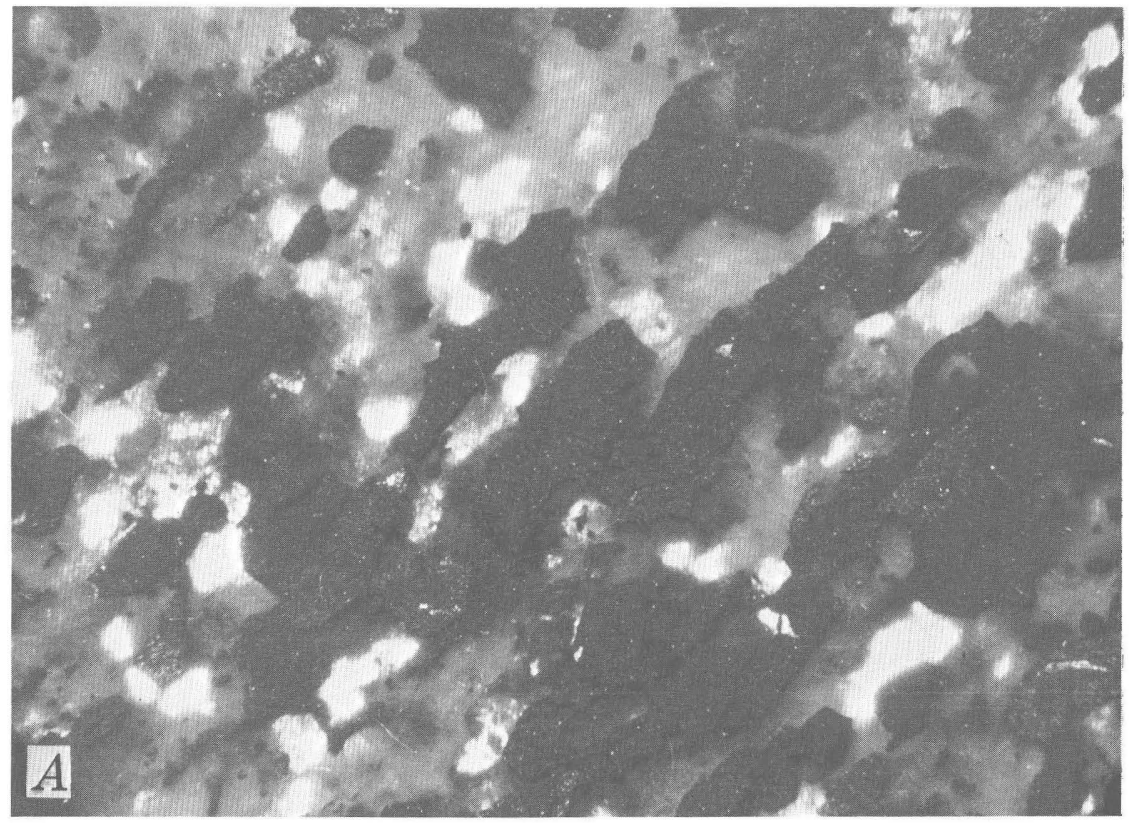

FIGURE 9.-Photomicrographs showing martite replaced by phosphate minerals. $A$, Core sample BB-40 at $13.1 \mathrm{~m}$ depth, iron oxide (black) partially replaced by amorphous phosphate minerals (gray); pore space is white; plane polarized and incident

Colors of surficial samples range from buff to brown, depending on the content of hydrous iron oxide. Colors of phosphate core samples are white, yellow, brown, red brown, and shades of gray. In one core sample, small spots of green turquoise were noted in white phosphate.

Densities of powders from outcrop samples are between 2.52 and 2.66, but the densities of powders from core samples vary by color: 2.45 for white to yellow phosphate rock, 2.90 for yellow-brown phosphate rock, and 2.92 for dark-brown phosphate rock. The density of samples of powdered phosphate rock from drill-hole BB-38 decreases from 3.11 at $3-\mathrm{m}$ depth to 2.36 at $38-\mathrm{m}$ depth, but this decrease in density with the depth of the sample was not observed for phosphate rock from other drill holes. No attempt was made to remove minor amounts of quartz, magnetite, and limonite. Thus, the above figures are bulk powder densities.

Differential-thermal-analysis (DTA) data on two outcrop samples showed strong endothermal reactions between $240^{\circ}$ and $260^{\circ} \mathrm{C}$ characteristic of clinostrengite and similar to data reported for this 


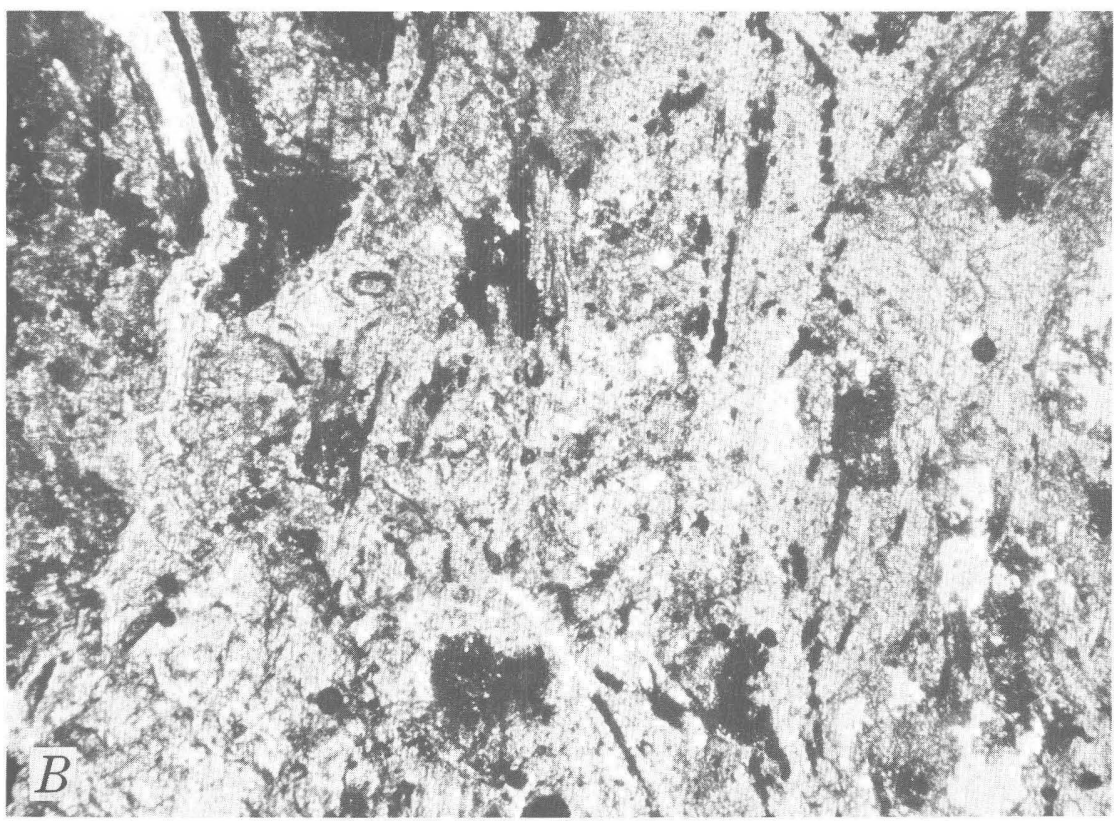

light, $\times 80 ; B$, Core sample BB-38 at $39.6 \mathrm{~m}$ depth, iron oxides (black) almost completely replaced by phosphate minerals (gray) and a late veinlet of phosphate minerals (near left side); plane polarized light, $\times 80$.

mineral by Rao and Da Cunha e Silva (1964, p. 298-299). In contrast, core samples yielded endothermal peaks that ranged between $255^{\circ}$ and $305^{\circ} \mathrm{C}$ for most specimens.

\section{OPTICAL PROPERTIES}

The presence of several phosphate minerals in the Bambuta deposit was confirmed by the optical properties of samples from outcrop and the subsurface. Outcrop samples were found by Srivastava (1971) to contain colorless and light-brown microcrystalline minerals. The colorless mineral, having refractive indices of 1.543 to 1.550 , probably is augelite, and the light-brown mineral, having indices of 1.585 to 1.615 , is iron-bearing variscite. An outcrop sample examined by a TVA laboratory was reported to have a mean refractive index of 1.615 , indicative of ferrian variscite. One outcrop sample of buff microcrystalline material was determined in the present investigation to have mass refractive indices that ranged from 1.725 to 1.730 , showing the minerals to be strengite or clinostrengite (Winchell and 
Winchell, 1951, p. 186-187). Core samples examined by the writers contained microcrystalline material and radial-columnar grains (fig. 10). The radial-columnar grains are from the late veinlets of crustified phosphate minerals (fig. 9B, left side). The microcrystalline material has indices between 1.65 and 1.73 and is most likely barrandite and strengite or their monoclinic analogs. The radial-columnar grains have indices between 1.59 and 1.62 and are variscite.

\section{X-RAY RESULTS}

Powder-camera and diffractometry methods of X-ray analysis were used to identify the phosphate minerals in 27 samples from 2 areas of outcrop and 8 drill holes. One outcrop sample was found by X-ray analysis to consist mainly of ferrian variscite and minor augelite (Charles Milton, written communication, 1969). Another outcrop sample from the southwest part of the deposit (RO-203A, fig. 8) was found by diffractometry methods to be mainly strengite (table 1). Sufficient data was available on this sample to obtain computerderived cell parameters; $a=10.163$ angstroms (A), $b=9.919 \mathrm{~A}$, $\mathrm{c}=8.783 \mathrm{~A}$, and cell volume, 885.32 cubic angstroms.

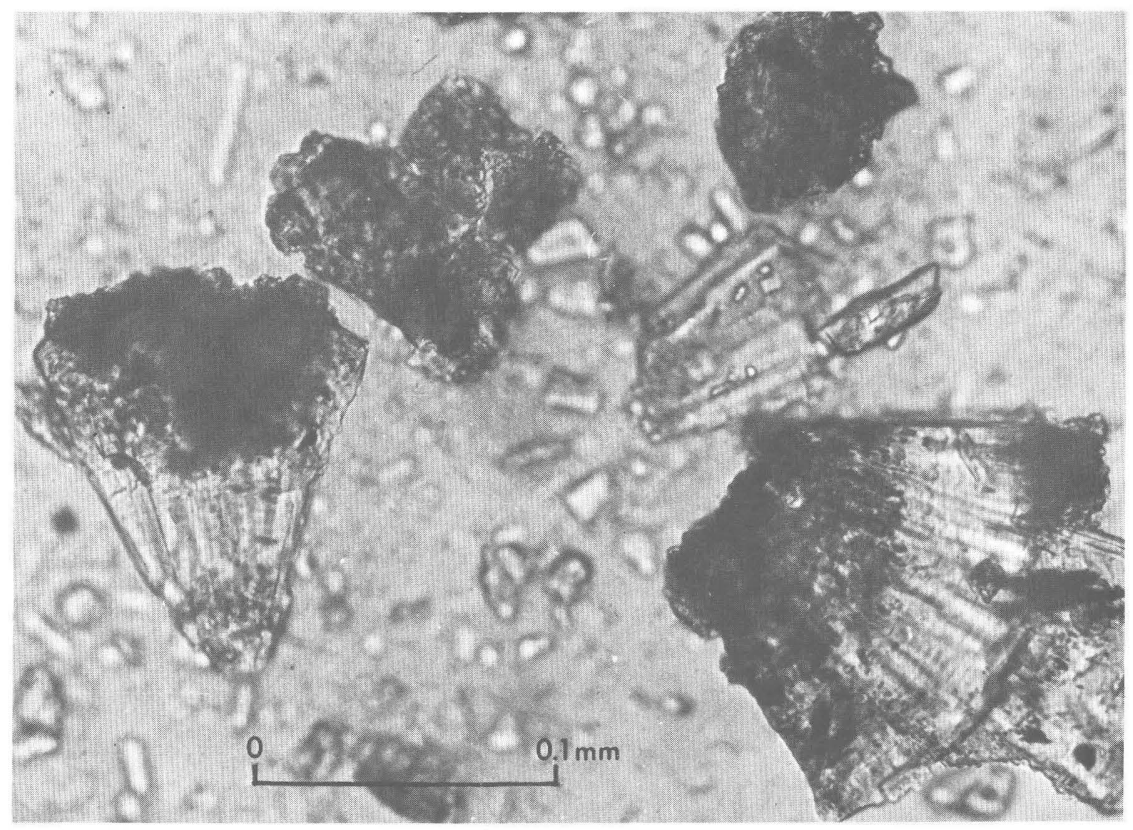

FIGURE 10.-Photomicrograph of a grain mount of phosphate minerals from drill-core BB-38 at $25.3 \mathrm{~m}$ depth, showing radial-columnar and microcrystalline grains. Refractive-index liquid is $1.54 ; \times 240$. 
In an earlier examination, X-ray diffraction data by J. B. Cathcart (written communication, 1971) indicated variable amounts of nine phosphate minerals plus quartz, goethite, and kaolinite in six core samples. The phosphate minerals he recognized are clinostrengite, strengite, barrandite, variscite, ferrian variscite, clinovariscite, augelite, barbosalite, and wavellite.

In this investigation, major and minor phases are identified in core samples as shown in table 2 .

It is apparent from the table that most of the Bambuta phosphate deposit near the crest of the ridge consists of iron-rich barrandite, strengite, clinobarrandite, and clinostrengite. Variscite is the major phase on the southeast side of the ridge in depth as well as near the surface. The heterogeneous mixture is undoubtedly the result of nonequilibrium conditions during the formation of the deposit. Epigenetic modification in the zone of weathering may have caused some of the heterogeneity.

TABLE 1.-X-ray powder diffraction data on strengite sample RO-203A from the phosphate deposit at Bambuta, Liberia

[Ni-filtered CuK $\alpha$ radiation=1.5418; analyst: Sam Rosenblum; strengite standard from Joint Committee on Powder Diffraction Standards card 15-513. Leaders, (--), indicate no data or not indexed]

\begin{tabular}{|c|c|c|c|c|c|c|c|c|c|c|c|c|c|}
\hline \multicolumn{4}{|c|}{$\mathrm{R} 0-203 \mathrm{~A}$} & \multicolumn{3}{|c|}{ Strengite Standard } & \multicolumn{4}{|c|}{$\mathrm{RO}-203 \mathrm{~A}$} & \multicolumn{3}{|c|}{ Strengite Standard } \\
\hline $\mathrm{d}(\AA)$ & & & & & & & $\mathrm{d}(\AA)$ & & & & & & \\
\hline $\begin{array}{l}\text { (obser- } \\
\text { ved) }\end{array}$ & $\begin{array}{l}\text { (calcu- } \\
\text { lated) }\end{array}$ & I & hkl & $d(\AA)$ & $\mathrm{I} / \mathrm{I}_{1}$ & hkl & $\begin{array}{l}\text { (obser- } \\
\text { ved) }\end{array}$ & $\begin{array}{l}\text { (calcu- } \\
\text { lated) }\end{array}$ & I & $h k 1$ & $d(\AA)$ & $\mathrm{I} / \mathrm{I}$ & hk1 \\
\hline 5.517 & 5.521 & 36 & 111 & 5.50 & 80 & 111 & -- & -- & --- & --- & 2.180 & 40 & $\overline{004,402}$ \\
\hline 4.959 & 4.959 & 45 & 020 & 4.95 & 60 & 020 & -- & $\ldots$ & - - & $\ldots$ & 2.134 & 10 & 133.104 \\
\hline 4.514 & 4.522 & 32 & 210 & --- & --- & --- & --- & -- & --- & --- & 2.101 & 40 & 142 \\
\hline 4.403 & 4.392 & 100 & 002 & 4.38 & 100 & 002,201 & 2.086 & 2.083 & 11 & 332 & 2.035 & 10 & -- \\
\hline 4.012 & 4.021 & 25 & 211 & 3.98 & 60 & 211,121 & -- & -- & -- & $\ldots$ & 2.001 & 10 & 223,204 \\
\hline 3.978 & 3.974 & 9 & 121 & -- & --- & --- & -- & -.- & $\ldots$ & -- & 1.956 & 10 & --- \\
\hline 3.729 & 3.735 & 8 & 112 & 3.72 & 40 & 112 & -- & --- & $\ldots$ & --- & 1.910 & 10 & -.- \\
\hline 3.548 & 3.549 & 17 & 220 & --- & -- & --- & 1.900 & 1.901 & 5 & 151 & 1.830 & 10 & --- \\
\hline-- & $\ldots$ & -- & -- & 3.29 & 20 & 022,202 & -- & -- & -- & -- & 1.803 & 20 & --- \\
\hline 3.162 & 3.161 & 8 & 301 & -- & -- & --- & 1.776 & 1.775 & 8 & 440 & 1.767 & 10 & -- \\
\hline 3.125 & 3.128 & 17 & 122 & 3.71 & 60 & 122,212 & 1.738 & 1.739 & 6 & 441 & -- & -- & -- \\
\hline 3.017 & 3.011 & 10 & 311 & 3.00 & 60 & 311 & 1.722 & 1.721 & 6 & 234 & 1.720 & 10 & --- \\
\hline 2.963 & 2.960 & 17 & 131 & 2.95 & 60 & 131 & 1.702 & 1.703 & 5 & 252 & 1.690 & 10 & -- \\
\hline 2.926 & 2.928 & 7 & 003 & --- & --- & -- & 7.664 & 1.663 & 12 & 601 & 1.650 & 20 & -- \\
\hline 2.875 & 2.813 & 19 & 103 & --- & --- & --- & 1.635 & 1.634 & 7 & 125 & --- & --- & --- \\
\hline 2.773 & 2.771 & 35 & 230 & --- & --- & --- & 1.631 & 1.632 & 8 & 160 & 1.625 & 20 & $-\ldots$ \\
\hline.-- & -- &.-- & -- & 2.69 & 10 & 113 & 1.608 & 1.610 & 7 & 334 & 1.602 & 10 & --- \\
\hline -- & -.- & -- & --- & 2.63 & 10 & 032.231 & 1.596 & 1.595 & 7 & 352 & 1.568 & 10 & -- \\
\hline 2.552 & 2.556 & 25 & 132 & 2.54 & 80 & 132 & 1.559 & 1.560 & 9 & 305 & 1.554 & 10 & $\ldots$ \\
\hline 2.524 & 2.521 & 12 & 023 & -- & -- & -. & -- &.- & --- & -.. & 1.540 & 10 & -- \\
\hline$-\cdots$ & -- &.-- & --- & 2.445 & 40 & 123,213 & 1.505 & 1.506 & 4 & 622 & --- & -- &.-- \\
\hline -.. & --- & --- &.-- & 2.400 & 10 & 140 & -- & --- & --- & -- & 1.478 & 10 & $-\ldots$ \\
\hline-- & -- & -- & -- & 2.360 & 10 & 411 & 1.436 & 1.437 & 4 & 710 & --- & $\ldots$ & -- \\
\hline 2.343 & 2.344 & 9 & 232 & -- & --- & -- & 1.387 & 1.387 & 10 & 425 & --- & --- & --- \\
\hline- & -- & --- & -- & 2.273 & 10 & 337 & 1.369 & 1.369 & 7 & 461 & $\ldots$ & --- & --- \\
\hline 2.229 & 2.228 & 6 & 240 & --- & --- & --- & -- & --- & -- & -- & --- & --- & -- \\
\hline
\end{tabular}


TABLE 2.-Phosphate minerals identified in drill cores

[V, variscite; $B$, barrandite; S, strengite; $\mathrm{CB}$, clinobarrandite; CS, clinostrengite. Leaders, (--), none]

\begin{tabular}{|c|c|c|c|c|c|}
\hline \multirow[b]{2}{*}{ Drill hole } & \multirow[b]{2}{*}{ Depth (m) } & \multicolumn{2}{|c|}{ Orthorhombic } & \multicolumn{2}{|c|}{ Monoclinic } \\
\hline & & Major & Minor & $\overline{\text { Major }}$ & Minor \\
\hline BB-38- & 3 & $B, S$ & --- & CB & CS \\
\hline $\mathrm{BB}-38$ & 9 & $\mathrm{~S}$ & --- & -- & $\mathrm{CB}$ \\
\hline $\mathrm{BB}-38-\cdots$ & 17 & S & --- & --- & CS \\
\hline BB-40 & 5 & -- & S & CS & --- \\
\hline $\mathrm{BB}-40-\cdots$ & 8 & --- & S & CS & $\mathrm{CB}$ \\
\hline BB $-41 \cdots$ & 6 & B & S & CB & $\mathrm{CS}$ \\
\hline$B B-42-\cdots$ & 18 & $S$ & --- & CS & -- \\
\hline BB-42 & 27 & B & S & --- & CS \\
\hline BB-52- & 4 & B & $S$ & --- & --- \\
\hline $\mathrm{BB}-53-\cdots$ & $2-7$ & $B$ & V & $C B$ & CS \\
\hline$B B-53 \cdots$ & $7-12$ & $B, S$ & --- & --- & --- \\
\hline BB-56- & $0-7$ & v & --- & --- & --- \\
\hline BB-57--n & $7-23$ & B & --- & --- & $\mathrm{CS}$ \\
\hline BB $-57 \ldots$ & 38 & V & --- & --- & -- \\
\hline
\end{tabular}

\section{CHEMICAL COMPOSITION}

Previously reported partial analyses of two outcrop samples of phosphate rock from the Bambuta deposit showed 35.71 percent $\mathrm{P}_{2} \mathrm{O}_{5}$ and 7.65 percent iron, and 31.88 percent $\mathrm{P}_{2} \mathrm{O}_{5}$ and 9.73 percent respectively (Srivastava, 1971). Partial analyses of core samples by the LMC laboratory indicate as much as 42.85 percent $\mathrm{P}_{2} \mathrm{O}_{5}$ where variscite is present. This is an unusually high value. In most of the other phosphate-bearing core samples the tenors averaged about 30 percent $\mathrm{P}_{2} \mathrm{O}_{5}$, and these tenors are the bases for the reserves discussed below.

More recent analyses of two outcrop samples are given in table 3 (Nos. 2 and 3). The method of analysis by the TVA laboratory (written commun., 1970) is not known. The analysis by E. L. Mosier was by emission spectrography, but $\mathrm{H}_{2} \mathrm{O}$ was determined by the senior author by weight loss on ignition after drying at $105^{\circ} \mathrm{C}$ to constant weight.

\section{ORIGIN OF DEPOSIT}

Any hypothesis for the origin of the Bambuta phosphate deposit must account for certain critical relations:

1. The lenticular layer of phosphate rock underlies a cap of enriched iron-formation as much as $35 \mathrm{~m}$ thick and replaces the iron ore along the contact. 
2. Minor lenses of iron-formation occur within and below the phosphate layer.

3. Bedding and foliation in phosphate rock and iron-formation are roughly conformable with the surface of the subjacent granitic gneiss.

4. The mineralogy of samples from 25 drill holes shows the composition of the phosphatic layer to range from iron to aluminum phosphates, the predominant mineral being aluminian strengite, the orthorhombic iron phosphate containing some aluminum. Aluminum phosphates are generally a minor component of this phosphate deposit.

5. Aluminum phosphate tends to increase and iron phosphate to decrease with increasing depth below the ground surface.

TABLE 3.-Chemical composition of phosphate samples from the Bambuta deposits, Liberia

[Leaders, (---), not reported]

\begin{tabular}{|c|c|c|c|c|c|}
\hline Sample & 1 & 2 & 3 & 4 & 5 \\
\hline $\mathrm{SiO}_{2} \ldots$ & --- & 11.4 & 15.2 & --- & --- \\
\hline $\mathrm{Al}_{2} \mathrm{O}_{3}-\cdots$ & 32.28 & 30.6 & 1.2 & 1.4 & --- \\
\hline $\mathrm{Fe}_{2} \mathrm{O}_{3}-\cdots$ & -- & 8.9 & 34.4 & 40.8 & 42.74 \\
\hline $\mathrm{P}_{2} \mathrm{O}_{5} \ldots$ & 44.93 & 32.9 & 32.2 & 38.1 & 37.99 \\
\hline $\mathrm{H}_{2} \mathrm{O} \cdots$ & 22.79 & 16.2 & 16.6 & 19.7 & 19.27 \\
\hline $\mathrm{TiO}_{2}$ & $-\cdots$ & --- & .4 & --- & --- \\
\hline Tota 1---- & 100.0 & 100.0 & 100.0 & 100.0 & 100.0 \\
\hline
\end{tabular}

SAMPLE DESCRIPTIONS

1. $\mathrm{ALPO}_{4} \cdot 2 \mathrm{H}_{2} \mathrm{O}$, variscite, ideal analysis.

2. Outcrop sample, analysis by TVA Division of Chemical Development.

3. Outcrop sample, spectrographic analysis by E. L. Mosier, U.S. Geological Survey.

4. Analysis 3 recalculated to 100 percent after removal of $\mathrm{SiO}_{2}$ and $\mathrm{TiO}_{2}$ values.

5. $\mathrm{FePO}_{4} \cdot 2 \mathrm{H}_{2} \mathrm{O}$, strengite, ideal analysis. 
Two equivocal modes of origin are possible for the Bambuta phosphate deposit: (1) metamorphism of an inorganic marine precipitate of Precambrian age; and (2) epigenetic replacement of underlying rock by phosphatic solutions from surficial guano deposits of late Tertiary or Holocene age.

Not enough field and laboratory data are available at present to permit a clear decision between these two modes of origin. Therefore, we present each one with discussions of pertinent processes involved. Additional field evidence may help to determine which mode is correct.

\section{MARINE PREGIPITATION}

The lack of clear biogenic evidence led us to seek information on the inorganic precipitation of phosphates and on the association of phosphates with iron-formation that would support an inorganic origin. A number of reports on inorganic formation of phosphate minerals describe geologic conditions that easily account for all the critical relations listed above.

Berge (1970, p. 1) noted that variscite and strengite are frequently described from environments that would tend to preclude the fecally instigated origin. He showed that variscite will form in acidic environments from interaction of phosphate ions, derived from apatite in iron-formation, with aluminum from clay minerals concentrated at or near the surface of iron-ore deposits such as those in the Nimba Range, Liberia. From experimental evidence and solubility calculations, he concluded that alumina and orthophosphoric acid ions combine at low $\mathrm{pH}$ to form aluminum phosphates which are relatively insoluble. Below $\mathrm{pH} 4$, provided sufficient alumina and phosphorus are present in solution, variscite or similar minerals should form. At $\mathrm{pH}$ higher than 4 , there is insufficient ionized aluminum to form these minerals (Berge, 1970, p. 5-6).

Iron-formation in western Liberia consists mainly of oxide and silicate facies (James, 1966, p. W12; White and Leo, 1969, p. 7-9; White, 1973, p. 8-10; Theinhaus and Stobernack, 1967, p. 53). The oxide facies is generally referred to as itabirite and comprises finely laminated rocks made up of quartz, iron oxide, and accessory minerals. The silicate facies consists of various proportions of quartz and iron-silicate minerals such as amphibole, pyroxene, garnet, and biotite, with or without iron oxide or pyrite, but where the ironformation has been affected by hydrothermal enrichment, as at Bomi Hills, other assemblages of silicate minerals have formed (White and Leo, 1969, p. 7). We believe that the oxide facies of the iron-ore deposit (magnetite and/or martite) at Bambuta, like that at Bomi Hills, was enriched. The enrichment may have been caused by 
postmetamorphic hydrothermal processes, but it also could have been caused by metasomatic replacement during greenschist- or epidote-amphibolite-facies metamorphism, but only at temperatures below $200^{\circ} \mathrm{C}$. The underlying phosphate had to be affected by the same processes, and probable changes within the phosphate layer are discussed below.

At the Bambuta phosphate deposit, the close association with interbeds of iron-formation, as defined by James (1966, p. W46), and its position below the main iron-formation indicate that the phosphate was deposited before the main layer of iron-formation. Although phosphorus, like iron, is present in small quantities in seawater, it may be precipitated in considerable quantities locally if the conditions are favorable. The association of iron silicates such as glauconite with some phosphatic deposits suggests that the environments of phosphorite and ironstone deposition have many factors in common (Pettijohn, 1957, p. 475-476). The mechanism of phosphate deposition involving marine organisms in a restricted part of post-Cambrian seas has been described by McConnell (1965), Youssef (1965), and McKelvey (1967), but these organic processes are unlikely to apply to a Precambrian deposit.

We believe that an origin of the Bambuta phosphate deposit by inorganic marine precipitation followed by low-grade metamorphism can explain the observed geologic relations. The following sequence of events is proposed:

1. Inorganic marine precipitation of calcium phosphate interbedded with thin layers of iron-formation occurred on a granitic gneiss terrane, followed by the deposition of a thick sequence of iron-rich sediments, at least 2,750 million years (m.y.) ago. This age is based on ages of schist and granitic gneiss from the Bong Mine deposit that were dated by Hedge, Marvin, and Naeser (1975, p. 426).

2. Low-grade regional metamorphism of the sediments enriched the iron-bearing sediments to iron ore and transformed the calcium phosphate to hydrous iron and iron-aluminum phosphates by metasomatic reactions. Along the contact between iron-formation and the phosphate layer each bed was affected by the chemistry of the other. The upper part of the phosphate layer was converted to iron phosphates by diffusion of iron from the overlying ironformation, which itself became somewhat phosphatic. The lower part of the phosphate layer became more aluminous than the upper part owing to the supply of aluminum from the underlying granitic gneiss.

Little is known about temperature-pressure conditions of stability of these phosphates. Considering DTA breakdown conditions of $215^{\circ}-300^{\circ} \mathrm{C}$ at one atmosphere pressure and extrapolating to moderate burial pressures at depths of 1-5 km, then these hydrous 
phosphates had to form at temperatures less than $200^{\circ} \mathrm{C}$, perhaps in the lowest grade of amphibolite facies conditions. If they are unstable under these conditions, then lower temperature postmetamorphic hydrothermal processes need to be invoked to explain the replacement of the original calcium phosphate by hydrous iron and aluminum phosphates. Either by metamorphic or hydrothermal processes, metasomatic fluids had to remove large quantities of silica from the iron-formation at the same time that similar large quantities of iron and aluminum replaced calcium in the phosphate layer.

Lacking definite criteria for metamorphic or hydrothermal effects in the phosphate rock as well as in the overlying iron ore, we are unable to decide which of these two processes was responsible for the enrichment of the iron ore and for the transformation of the phosphate minerals in the Bambuta deposit. However, during or after metamorphism, plastically squeezed phosphate filled open fractures in and partly replaced the more dense and brittle iron ore along the contact, completely enclosing some iron-ore breccia (fig. 6). The metamorphism probably took place during the 1,600-m.y. metamorphic event (Stobernack, 1968, p. 46-49); similarly, a postmetamorphic injection and replacement of iron-formation by the underlying phosphate could have been as young as the $500 \pm$ m.y. Pan-American event (Hedge and others, 1975, p. 426).

3 . Erosion stripped most of the overlying metasedimentary rocks, leaving a synclinal relic that is more resistant than the surrounding crystalline rocks. Near-surface chemical reactions of iron and ironaluminum phosphates with aluminous materials favors replacement of relict iron phosphates by aluminum phosphates. Thus, we infer that aluminum phosphates in this deposit may have had two modes of origin: (1), metamorphic replacement of calcium phosphate at depth during Precambrian time, and (2), surficial replacement of iron phosphate in Holocene time. The aluminum phosphates produced by these two processes should be different minerals, but we are unable to confirm this at present.

\section{BIOGENIC ORIGIN}

A biogenic origin for the iron phosphate minerals at Bomi Hills was proposed by Axelrod, Carron, Milton, and Thayer (1952, p. 883) who believed that they "****formed by the interaction of bat dung, or substances derived from it, with exposed iron oxide***the phosphates from Bambuta differ from those at Bomi Hills; the difference, however, may reflect incomplete knowledge of the two deposits rather than any significant difference of origin. In both, the source of the phosphorus is believed to be the dung of bats." 
In support of a biogenic origin, a test of the radioactivity of 12 powdered drill-core samples and one outcrop sample from the Bambuta deposit showed a maximum of 0.002 percent uranium. The data falls in the range of uranium (0.001 to 0.003 percent) indicated by Cathcart (1978) for phosphates derived from guano deposits. The range for uranium in marine phosphorites $(0.005$ to 0.030 percent uranium) is at least 5 to 10 times greater.

Precipitation of phosphate minerals from guano-derived solutions is a simpler process than the marine-precipitation-andmetamorphism mode discussed above, but there is no evidence, at present, of a guano source for the phosphatic solutions. Presuming that such a source did exist long enough to supply all the phosphate in the Bambuta deposit, we propose the following history:

1. At least 2,750 m.y. ago (Hedge and others, 1975, p. 426), ironrich sediments were deposited on a granitic terrane, and these were metamorphosed to iron-formation and granitic gneiss.

2. In late Tertiary or Holocene time, while this terrane was still exposed and probably at shallow depth, guano-derived phosphatic solutions traveled laterally along the contact between the iron-formation and the granitic gneiss, and both rock types were replaced by phosphate minerals. Iron phosphates were formed from ironformation, and aluminum-rich phosphates were formed from granitic gneiss. The foliation in each rock type was preserved in places by the new phosphate materials.

3. During or after replacement by the phosphatic solutions, fracturing in the iron-formation took place, and phosphate minerals worked upward into open fractures by plastic deformation (fig. 6).

4. Erosion in Holocene time stripped the guano source of the phosphatic solutions and part of the iron-formation through which the solutions penetrated. The remaining iron-formation supports the crest of the ridge over the phosphate deposit.

\section{RESERVES}

Stewart, Dinkins, and Freeman (1969) indicated 450,000 metric tons of phosphate rock in the Bambuta phosphate deposit, but the basis for these reserves was not given. Data from 25 drill holes that intersected the phosphate rock were used in conjunction with geologic maps and cross sections by Peter Van Rooijen (written commun. 1971) to calculate a minimum reserve of 1.5 million metric tons of phosphate rock containing 28 percent $\mathrm{P}_{2} \mathrm{O}_{5}$ or 1 million tons containing 32 percent $\mathrm{P}_{2} \mathrm{O}_{5}$. These estimates are tentative because the structure is not well enough known to permit a valid interpretation of the number of phosphate layers and their true thicknesses. 


\section{POTENTIAL USE}

Little is known about the release of phosphate from iron-rich members of the variscite-strengite series of phosphate minerals. Inasmuch as aluminian strengite is the apparent major mineral in the Bambuta deposit, the treatment required to make the phosphate available will affect the potential use of the phosphate rock as fertilizer.

Untreated phosphate rock from the Bambuta deposit was compared by LAC to imported calcium phosphate fertilizer and found to be deficient in its release of phosphate. Experiments were then undertaken by TVA to determine the effects of calcining the phosphate rock at $300^{\circ} \mathrm{C}$. The results showed that calcining caused 20 to 25 percent of the total phosphate to become citrate soluble and thus available to plants.

A study of the uptake of phosphorus by corn from amorphous aluminum phosphate indicated that crop yields in acid soil ( $\mathrm{pH}$ 5.5) were between 60 and 70 percent of those from soils to which a comparable application of monocalcium phosphate had been made, but that in calcareous soil ( $\mathrm{pH} 8.5$ ), both amorphous aluminum phosphate and the crystalline phase, variscite, were better sources of phosphate than monocalcium phosphate (Taylor and others, 1963, p. 150). Thus, lime is required with aluminum phosphates to ensure adequate availability of phosphate to plants.

From general chemical considerations under surface conditions, iron phosphates are somewhat more water soluble than aluminum phosphates and presumably they would yield more phosphate ions. However, in acidic soils such as those overlying the laterite of Liberia, the phosphate ions are likely to precipitate rapidly as a relatively insoluble aluminum phosphate before they can be taken up by plants. Clearly, iron-bearing phosphates from the Bambuta area, though they may not need heat treatment, will require the addition of lime to keep the phosphate ions available.

Local sources of limestone and marble for producing lime are unknown in Liberia. However, lime may be made from deposits of marine shells on the beaches of eastern Liberia or in offshore seabottom deposits. These shells could be recovered easily and roasted for lime. Tests by the LGS Mineralogy Laboratory showed that up to 60 percent by weight of the beach sand consists of shells and shell fragments coarser than one-eighth of a millimeter (120-mesh, U.S. Standard screen). Similarly, shell fragments coarser than 120-mesh make up as much as 85 percent by weight of the sea-bottom sediments in the vicinity of Cape Mount. Presumably the same percentage of shells may be found in other offshore areas of Liberia. 


\section{RECOMMENDATIONS}

The estimated reserve of 1.5 million metric tons of high-grade phosphate rock justifies the formulation of plans for mining and marketing. A feasibility study is recommended for the possible mining and marketing of the material in this deposit for its obvious fertilizer potential. Other studies are recommended to determine the use of these phosphates in detergents, baking powder, ceramics, sugar refining, water softeners, pharmaceuticals, dental cements, fireproofing materials, and other industrial products. Detailed geologic mapping and additional drilling should be done to permit accurate calculation of reserves of phosphate rock. Further analyses of phosphate samples are required from surface and subsurface locations to ascertain the range in grade of $\mathrm{P}_{2} \mathrm{O}_{5}$ in this material. Additional mineralogical work is recommended to detect changes in mineralogy from place to place in the deposit that could have critical effects on utilization.

\section{REFERENCES CITED}

Axelrod, J. M., Carron, M. K., Milton, C., and Thayer, T. P., 1952, Phosphate mineralization at Bomi Hill and Bambuta, Liberia, West Africa: American Mineralogist, v. 37, nos. 11-12, p. 883-909.

Behrendt, J. C., and Wotorson, C. S., 1974, Aeromagnetic map of the Monrovia Quadrangle, Liberia: U.S. Geological Survey Map I-775 B., scale 1:250,000, 1 sheet.

Berge, J. W., 1968, A proposed structural and stratigraphic interpretation of the Nimba-Gbahm Ridge area, Liberia: Geological, Mining, and Metallurgical Society of Liberia Bulletin, v. 3, p. 28-47.

1970, Implications of phosphorus fixation during chemical weathering in the genesis of supergene iron ores: Geological, Mining, and Metallurgical Society of Liberia Bulletin, v. 4, p. 33-43 [1971].

Cathcart, J. B., 1978, Uranium in phosphate rock: U.S. Geological Survey Professional Paper 988-A, 6 p.

Hedge, C. E., Marvin, R. F., and Naeser, C. W., 1975, Age provinces in the basement rocks of Liberia. U.S. Geological Survey Journal of Research, v. 3, no. 4, p. 425-429.

James, H. L., 1966, Chemistry of the iron-rich sedimentary rocks, in Data of geochemistry (6th ed.): U.S. Geological Survey Professional Paper 440-W, p. W1-61.

McConnell, Duncan, 1965, Precipitation of phosphates in seawater: Economic Geology, v. 60, no. 5, p. 1059-1062.

McKelvey, V. E., 1967, Phosphate deposits: U.S. Geological Survey Bulletin 1252-D, p. D1-D21.

Pettijohn, F. J., 1957, Sedimentary rocks (2d ed.): New York, Harper and Bros., 718 p.

Rao, A. B., and da Cunha e Silva, Judson, 1964, Differential thermal analysis of some Brazilian phosphates: Anais da Academia Brasiliera Ciencias, v. 36, p. 295-303. 
Srivastava, S. P., 1970, Mineralogy of phosphate rock from Bambuta: Geological, Mining, and Metallurgical Society Liberia Bulletin, v. 4, p. 26-32 [1971].

Stewart, W. E., Dinkins, D. A., and Freeman, W. A., 1969, Field investigation of Lot No. 3 near Bambuta, Lofa County: Liberia Geological Survey Memorandum Report 53, 9 p.

Stobernack, Just, 1968, Stratigraphie und Metamorphose des prekambrischen Grundgebirges der Bong Range in Liberia: $\mathrm{Ph}$. D. thesis, Technische Universitat Clausthal, Germany, $185 \mathrm{p}$.

Taylor, A. W., Lindsay, L., Huffman, E. O., and Gurney, E. L. 1963, Potassium and ammonium taranakites, amorphous aluminum phosphate, and variscite as sources of phosphate for plants: Soil Science Society of America Proceedings, v. 27 , no. 2 , p. $148-151$.

Thienhaus, R., and Stobernack, J., 1967, Investigations on facies, metamorphism, and tectonics of the Precambrian basement of the Bong Range, Liberia: Geological, Mining, and Metallurgical Society of Liberia Bulletin, v. 2, p. 48-58.

White, R. W., 1973, Progressive metamorphism of iron-formation and associated rocks in the Wologizi Range, Liberia: U.S. Geological Survey Bulletin 1302, 50 p. [1974].

White, R. W., and Leo, G. W., 1969, Geological reconnaissance in western Liberia: Liberia Geological Survey Special Paper 1, 18 p.

Winchell, A. N., and Winchell, Horace, 1951, Elements of optical mineralogy, Part II, Descriptions of minerals (4th ed.): New York, John Wiley and Sons, 551 p.

Youssef, M. I., 1965, Genesis of bedded phosphates: Economic Geology, v. 60, no. 3, p. $590-600$. 




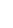


